\title{
A new Paxillus MacLeay, 1819 (COLEOPTERA: PASSALIDAE: PASSALINAE) from the state of Amazonas, Brazil
}

Claudio Ruy Vasconcelos da FONSECA¹, Fernando Bernardo Pinto GOUVEIA², Maria Fernanda Souza FERNANDEZ ${ }^{3}$.

\section{ABSTRACT}

Paxillus is a neotropical genus belonging to the subfamily Passalinae widespread from Mexico to Argentina. Brazil is known to harbor five species belonging to this genus with most of them presenting at head a flattened central tubercle lacking a free apex. However, one of these species, Paxillus macrocerus Reyes-Castillo \& Fonseca, differs from that pattern by having a long central tubercle with a completely free apex. The present study describes and illustrates another new species, which has been found in the Brazilian Amazon, showing this same characteristic.

KEY WORDS: Coleoptera, Passalidae, Paxillus, Taxonomy, Brazil

\section{Um novo Paxillus MacLeay, 1819 (COLEOPTERA: PASSALIDAE: PASSALINAE) do Estado do Amazonas, Brasil}

\section{RESUMO}

Paxillus é um gênero neotropical pertencente à subfamília Passalinae, distribuído do México até a Argentina. No Brasil são conhecidas cinco espécies desse gênero, a maioria delas apresentando um tubérculo central achatado sem ápice livre. Entretanto, uma dessas espécies, Paxillus macrocerus Reyes-Castillo \& Fonseca, apresenta um padrão diferente, tendo em vista que possui um tubérculo central longo com o ápice completamente livre. O presente estudo descreve e ilustra outra espécie nova, a qual foi encontrada na Amazônia brasileira, que apresenta essa mesma característica.

PalavraS-Chave: Coleoptera, Passalidae, Paxillus, Taxonomia, Brasil

1 Instituto Nacional de Pesquisas da Amazônia, rclaudio@inpa.gov.br

${ }^{2}$ Instituto Nacional de Pesquisas da Amazônia, fpinto@inpa.gov.br

3 BIOAMAZÔNIA,fernandabioamazonia@fucapi.br 


\section{INTRODUCTION}

The genus Paxillus MacLeay, 1819 occupies a huge territory in the Neotropical Region from Mexico to Argentina. Brazilian species, such as Paxillus leachi MacLeay, have a wide distribution, covering a range from the northernmost to the southernmost Brazilian Pampas region, including areas westward from its border, like the Andean region, always found colonizing trunks in decomposition. In general, the features defining the Paxillus are conspicuous; like the central tubercle of the head which is flattened, with no free apex, antenna with five lamellae, pentagonal prosternelum and onehooked lacinia. Reyes-Castillo \& Fonseca (1992) described, from the state of Rondônia, Brazil, a species having a long central tubercle with the apex broadly free. Now another species with a similar central tubercle has been found in the Brazilian State of Amazonas, that is described below.

\section{Paxillus corniculatus n.sp.}

(figures 1 to 6)

Head - Frontal area transverse, with strong punctures; anterior edge of the head straight notched in the middle. Frontal ridges (Figure 1) semi circular in shape ending on internal tubercule that is small or inconspicuous. Frontal middle structure like "striatopunctatus" - type (sensu ReyesCastillo, 1970) with large and flattened central tuberculum having free apex; parietal tubercule inconspicuous or absent. External tubercule big. Profound frontal depression strongly punctate. Ocular keel presenting rounded canthus. Occipital groove almost erased medially. Eyes large. Five antennal lamellae (Figure 1) forming a straight line when close together. Labrum with the anterior edge lightly concave, surface covered with scattered long and thin setae. Three apical teeth on both mandibles (Figures 2 and 3); dorsal tooth elevated. Lacinia
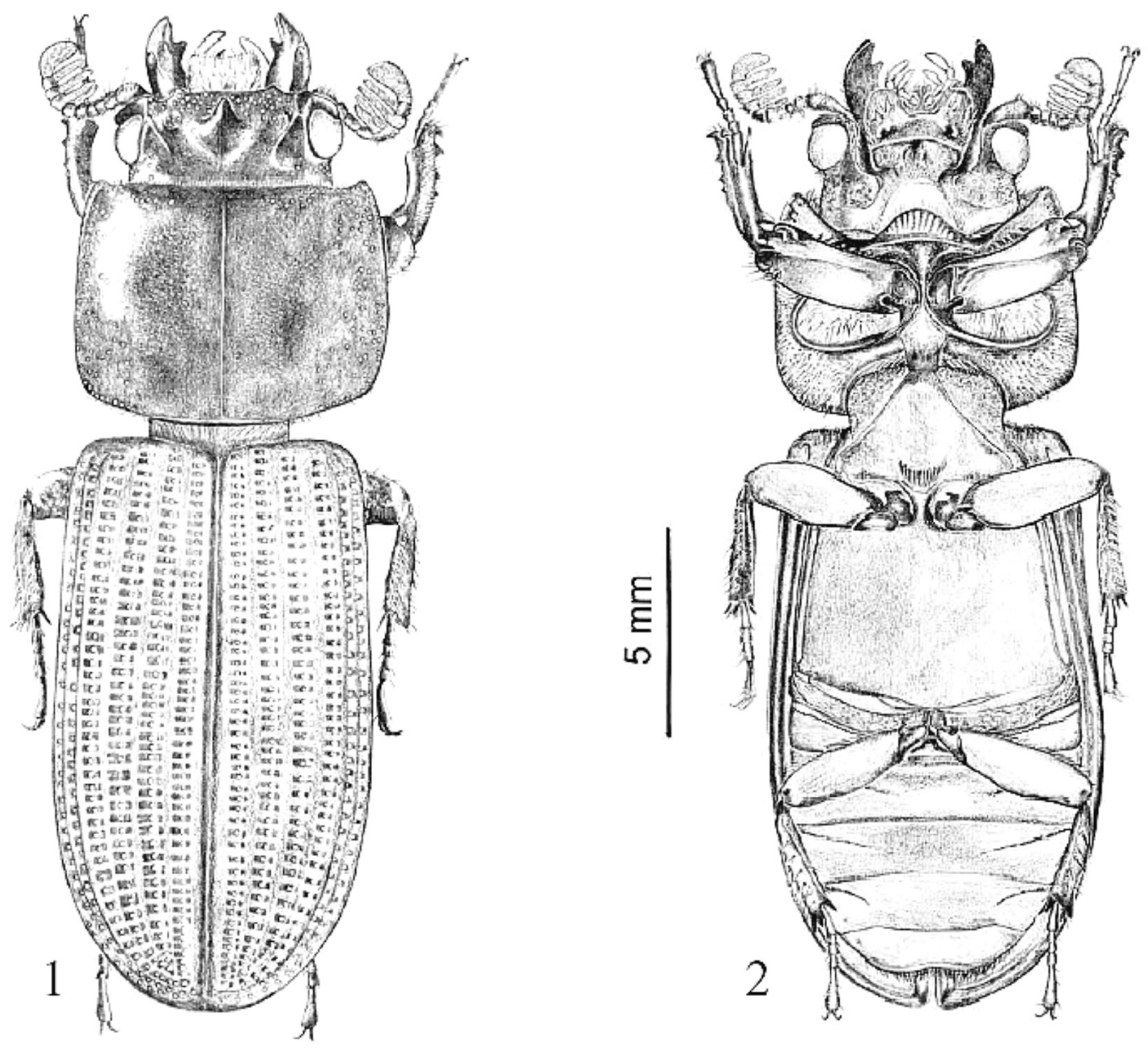

Figures 1-2 - Paxillus corniculatus n. sp. (Dorsal, ventral). Figs with the same scale. 


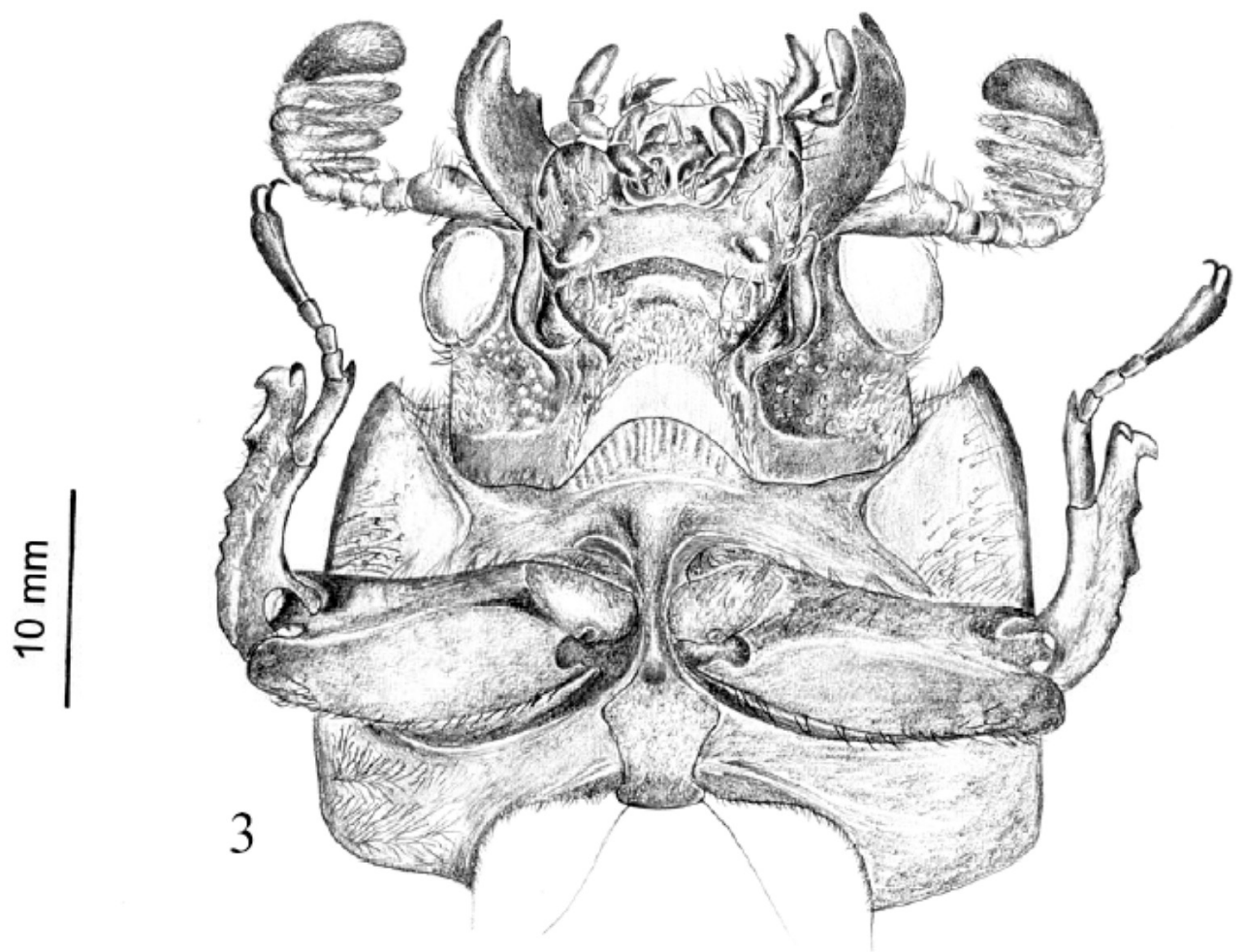

Figure 3 - Paxillus corniculatus head in ventral view
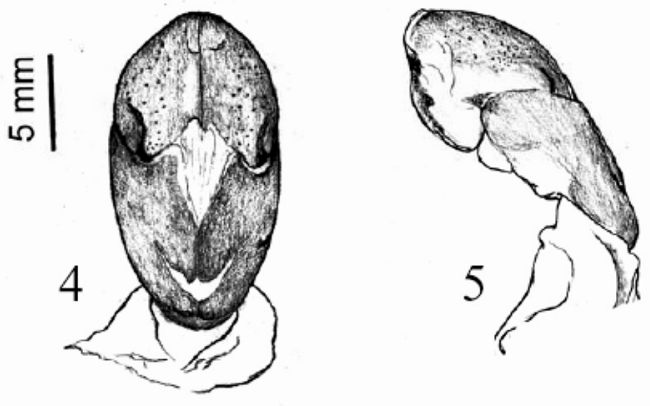

with one apical tooth. Menthum (Figure 3) with large lateral lobes; deep and large basal foveae; medial area of mentum smooth and glabrous; hypostomal process (Figures 2 and 3) close to the mentum; ligula with three teeth; cavity of the labial palpi cavity insertion large and separated by thin keel (Figure 3).

Thorax - Prothorax (Figure 1) with straight anterior edge; anterior angles more or less prominent. Medial groove straight. Anterior grooves narrow, reaching far beyond the middle with punctures. Pronotal depression with strong punctures. Lateral area of the pronotum with strong and dense punctuation. Prosternellum (Figure 3) pentagonal in shape but the posterior part presents a conspicuous constriction. Mesosternum (Figure 2) glabrous, having discrete, small and smooth depression. Metasternum (Figure 2) completely glabrous and smooth, disc not delimited; metasternal scars slender and smooth. Elytra (Figure 1) having humeri not densely setose; medial and lateral striae marked with strong punctures. Tibia I (Figure 3) having four teeth and pointed apical spur. Tibia II and Tibia III (Figure 2) having two or three lateral spurs.

Abdomen - Six visible sternites. Aedeagus (Figures 4 to 6) with basal piece and lateral lobes fused; mid lobe with sclerotized area on ventral and lateral faces presenting marked spots; mid lobe as long as basal piece and lateral lobes together.

Type material - Holotype $\hat{\sigma}$. BRASIL. Amazonas: Manacapuru, 06.VI.1989 (Luiz Aquino), INPA. Paratypes: Idem, 1 ふ઼, 7 오, INPA. 
Etymology - The name refers to the presence of a significant horn on the head.

Taxonomic discussion - Paxillus corniculatus is the second species described from the Brazilian Amazon region having a central tuberculum with long and free apex. The other one is Paxillus macrocerus Reyes-Castillo e Fonseca, 1992 which has the central tuberculum apex surpassing the frontal edge of the head. P. corniculatus differs from P.macrocerus mainly on account of the prosternelum which has a conspicuous constriction at the posterior part (Figure 3), and by the central tuberculum that does not go further than the head anterior edge.

\section{LITERATURE CITED}

Reyes-Castillo, P. 1970. Coleoptera, Passalidae: morfología y division en grandes grupos, gêneros americanos. Folia Ent. Mexicana, 20-22: 1-240.

Reyes-Castillo, P. \& Fonseca, C.R.V. 1992. Contribución al conocimiento de Paxillus MacLeay, com la descripción de uma nueva espécie amazónica (Coleoptera: Passalidae). Folia Ent. Mexicana, 84: 15-33.

Recebido em 06/03/2008

Aceito em 16/06/2008 